\title{
Service quality in product development companies: a study using the SERVQUAL tool
}

\author{
Patrícia Pereira Arantes Inácio, Sandra Miranda Neves \\ Universidade Federal de Itajubá \\ e-mails: pati.arantes@hotmail.com; sandraneves@unifei.edu.br
}

\begin{abstract}
In order for a new product to achieve the expected success, it is necessary that the author of the project's design be able to offer a service with quality and in accordance with what the client expects. However, due to the unique characteristics of the services, it is difficult to measure their quality. Due to this difficulty, the SERVQUAL tool was developed, aiming to quantify the quality of the service provided by comparing expectations and perceptions of customers. The main objective of this research is to evaluate the quality of the services provided by a product development organization using the SERVQUAL tool. Therefore, through a case study, 37 of the studied company clients received a questionnaire. The main results of the research were the validation of the use of the SERVQUAL as a tool to evaluate the quality of the services of a product development company, the reliability dimension has the greatest discrepancy between expectations and perceptions, and the empathy dimension represents the strength of the organization studied.
\end{abstract}

Keywords: product development company, dimensions of quality, SERVQUAL.

\section{Introduction}

The consumer itself through comparison must evaluate the quality of a given service, that is, the consumer compares what wishes to receive against what effectively receives (CUKIER; COSTA, 2013). Thereby, the service quality is not exclusively dependent on the service provided, but also on the expectations of the service (GRÖNROOS, 2003).

For the success of a newly launched product is necessary that the project creator offers a service with the quality awaited by the customer. Although, given the unique features of the services (intangibility, heterogeneity, perishability, inseparability), it is hard to measure its quality (NOGUEIRA; LAS CASAS, 2009). Another difficulty encountered in the chase for quality in services is that it depends on subjective factors of hard operationalization about the relationship between the provider and its clients. Which makes the search for quality a hard task, due to the need to read feelings and expectations and transform into evaluation parameters (PEREIRA; CARVALHO; ROTONDARO, 2013).

Because of this difficulty, Parasuraman, Zeithaml and Berry (1985) created the 5 Gaps model. The authors found discrepancies (gaps) between the expectations and the perceptions of the clients on the service provided, which implies in the satisfaction and consequently in the quality of the service (MACÊDO et al., 2013; BACCARO; GALÃO, 2012). From this model, Parasuraman, Zeithaml and Berry
(1985) developed the SERVQUAL tool for perceived quality evaluation. Therefore, the following questions guide this research: how can a product development company evaluate the quality of its services? Which quality dimension has the biggest and the smallest gap between the expectations and perceptions of the clients? Moreover, which strategies the company can apply once knowing its strengths and weaknesses?

The main goal of this research is to evaluate the quality of services provided by a product development company with the SERVQUAL tool. Its specific goals are to analyze the use of the SERVQUAL tool as service's quality evaluation, identify the gaps between client's expectations and perception while presenting the strengths and weaknesses of the company, and evaluate expectations and perceptions of clients over the dimensions reliability, responsiveness, safety, empathy, and tangibility.

The given research is a case study in a service provider company, with a focus on product development, situated in the city of Santa Rita do Sapucaí, Minas Gerais (Brazil). The case study is based on the steps defined by Miguel (2007).

The propositions, obtained from a literature analysis on the subject and evaluated from the results found, are: (i) Proposition 1: it is possible to measure the quality of services provided by a mechanical products company 
using the SERVQUAL tool; (ii) Proposition 2: the dimensions reliability and responsiveness will have the smallest gap, representing the strengths of the given organization; (iii) Proposition 3: the dimension tangibility is the weaknesses of the organization, and thus the need to prioritize it in order to decrease the existing gap.

The research subject is relevant because, according to Armond and Horta (2010, p. 5), "[...] the core value of a product based on service is the output of the interaction buyer-seller [...]"; this means that the relationship between client and supplier is crucial for proper delivery of the service. Hence the importance of measuring service quality from the customer's perspective.

The structure of the paper is as follows: Section 1 presents the introduction on the subject, covering the research question, the objectives, the justifications and the research method adopted. Section 2 contemplates the theoretical reference on quality in services and on the SERVQUAL tool. Section 3 deals with Materials and Methods. Section 4 discusses the application of the SERVQUAL tool and the results and discussions. Finally, Section 5 presents the conclusions and suggestions for future research.

\section{Evaluation of quality in services}

\subsection{Quality in services}

According to Zeithaml and Bitner (2003, p. 28), "[...] services are acts, processes, and performances, as well as every economic activity whose product is not physical or built." At the time services are produced they are consumed, they are perishable, their consumption occurs the moment they are produced, they are variable and provide benefit in the form of convenience, fun, timesaving's, comfort or health. The services are dedicated to those who buy them (NOGUEIRA; LAS CASAS, 2009).

Assuming that the main quality referential is its customer perception, Gonçalves and Belderrain (2012) cite that the quality of services is quite unique, since it depends on subjective characteristics such as "behavior, time, appearance, performance, precision"; Which implies that the concept of quality in the service sector is challenging to define (MACÊDO et al., 2013; AL-ROUSAN; MOHAMED, 2010).

In view of the current market and its incessant competition, quality is one of the main differentiating concepts of companies in the quest for a competitive position (TEIXEIRA; MEDEIROS; LEE HO, 2012). Thequality of services, therefore, has been used as a strategic alternative to consolidate and increase the performance of companies (GRÖNROOS, 2009).

Consumers have been much more demanding, critical and well informed about the products and/or services they consume as, due to economic globalization and high competitiveness among companies, there has been a saturation of products on the market and an increase in the options of choice (MINCIOTTI; SANTOLIA; KASPAR, 2008). These factors stimulate the companies that work in this sector to offer a better quality of the services provided, as a way of adding value (ZANCAN; SANTOS; COSTA, 2013).

Services are recognized as the sector that is characterized by the provision of an intangible benefit and this makes it demanding to quantify by effective measures of performance (ALMEIDA, 2013). The quality of the service provided must be evaluated by the consumer through comparison, that is, the consumer compares what he wants to receive with what actually is received (CUKIER; COSTA, 2013). Thus, the quality of the service does not depend only on the service itself, but also on the very nature of the expectation about the service provision (GRÖNROOS, 2003). Therefore, before purchasing a service, consumers evaluate their individual needs, past experiences, and third-party recommendations. Once met the customer expectations, they can become loyal customers (GONÇALVES; BELDERRAIN, 2012).

Parasuraman, Zeithaml and Berry (1988) point out three basic characteristics for the quality of services: clients find it more difficult to evaluate the quality of services than to a product; Perceptions of quality in services are a result of comparing consumer expectations and final performance; Quality assessments depends not only on the end result of the service but also on the service delivery process (CUKIER, COSTA, 2013).

Las Casas (2007, p. 121) explains, "[...] service delivery is based on human performance, and good service depends on the quality of this performance." For Grönroos (2003), the success of relationship marketing depends immensely on employee attitudes, commitment and performance.

In the absence of objective measures, an adequate approach to evaluate the quality of a company's services is to measure the perception of the consumers about their quality, which can be done by the SERVQUAL scale (OLIVEIRA et al., 2012).

\subsection{The SERVQUAL tool}

According to a study carried out by the authors Arantes and Neves (2014), SERVQUAL stands out as the most used tool for measuring the quality of services, representing $43 \%$ of the 142 articles analyzed. With regard to the most recent articles (2012 to 2014), they were analyzed regarding the information of the tool used and the area of application (Table 1).

The percentage of studies carried out in higher education institutions is significant (17\%). It is also possible to verify the variety of areas for application of the SERVQUAL tool, including internal clients of industries and military organizations. As expected, the authors most cited in the 
Table 1. The diversity of tools and application areas.

\begin{tabular}{|c|c|c|c|}
\hline Year & Author (s) & Tool & Application area \\
\hline 2014 & Lee and Kim & DEA & Car workshop \\
\hline 2014 & Papanikolaou and Zygiaris & SERVQUAL & Basic healthcare centers \\
\hline 2014 & Sheikh & SERVQUAL & Higher education library \\
\hline 2014 & Ariza, Garcia and Delgado & $\begin{array}{c}\text { Developed by the } \\
\text { authors }\end{array}$ & Healthcare Center \\
\hline 2013 & Tseng and Hung & SERVQUAL & Green products developer \\
\hline 2013 & Yeo and $\mathrm{Li}$ & SERVQUAL & Higher education institution \\
\hline 2013 & Lupo & SERVQUAL & Higher education institution \\
\hline 2013 & Pena, Silva, Tronchin and Melleiro & SERVQUAL & Healthcare center \\
\hline 2013 & Jia and Reich & IT Service Climate & Insurance Company \\
\hline 2013 & Wong & SERVQUAL & Public library \\
\hline 2013 & Fotiadis and Vassiliadis & SERVQUAL & Healthcare system \\
\hline 2013 & Kim, Blanchard, DeSarbo and Fong & SERVPERF & National insurance company \\
\hline 2013 & Zhao, Di Benedetto & SERVQUAL & Maintenance and sale of computer software \\
\hline 2013 & Murillo and Saurina & $\begin{array}{l}\text { Developed by the } \\
\text { authors }\end{array}$ & Healthcare posts \\
\hline 2013 & Miller, Hardgrave and Jones & ISS-QUAL & Maintenance of Information Systems Software \\
\hline 2012 & Margaritis, Katharaki and Katharakis & SERVPERF & Airlines \\
\hline 2012 & $\begin{array}{c}\text { Rajab, Shaari, Panatik, Wahab, Rahman, Shah } \\
\text { and Ali }\end{array}$ & SERVPERF & Higher education institution \\
\hline 2012 & Saraei and Amini & SERVQUAL & Telecommunications services in rural areas \\
\hline 2012 & Kontic & SERVPERF & Higher education institution \\
\hline 2012 & Elling, Lentz, Jong and Bergh & WEQ & Evaluation of government websites \\
\hline 2012 & Vaijayanthi, Shreenivasan and Roy & SERVPERF & Fast-food restaurant \\
\hline 2012 & Ihtiyar and Ahmad & RSQS or DTR & Food retailer \\
\hline 2012 & Calabrese and Scoglio & $\begin{array}{l}\text { Developed by the } \\
\text { authors }\end{array}$ & Appliance industry \\
\hline 2012 & Joo, Choi and Suh & SERVQUAL & Shopping Center \\
\hline 2012 & Aguwa, Monplaisir and Turgut & $\begin{array}{l}\text { Developed by the } \\
\text { authors }\end{array}$ & $\begin{array}{l}\text { Method to evaluate the quality of services that use } \\
\text { the voice of the client }\end{array}$ \\
\hline
\end{tabular}

Source: Arantes and Neves (2014).

articles analyzed were Parasuraman, Zeithaml and Berry (1988), with 56.8\%.

The client's expectations and perceptions of the service gives the process done by the client to evaluate the service quality (SULIEMAN, 2013). In this way, Parasuraman, Zeithaml and Berry (1985) developed the SERVQUAL tool, assuming that the quality of services can be measured through a function that addresses the differences between expectation and performance/perception along the analysis of the dimensions of quality. They have concluded that there are five types of Gaps between what the service producer offers and what the customer who enjoys this service perceives. In this way, the authors created the 5 Gaps Model (MACÊDO et al., 2013; FITZSIMMONS; FITZSIMMONS, 2010).

According to Chikwendu, Ejem and Ezenwa (2012), the first Gap addresses the discrepancy between user expectations and managerial perceptions; the second addresses the difference between the managerial perception of user expectation and specification of quality in service. The third Gap addresses the gap between the specification of quality in the service and the service offered. The fourth addresses the discrepancy between the service offered and what was communicated to the user. And the last Gap talks about the discrepancy between what the user expects to receive and the perception he has of the service offered (LARGE, KONIG, 2009).

The first four Gaps make up the fifth, which reflects the differences between the customer's expectations regarding the service they are acquiring or considers ideal and their perception of performance. It follows from Equation 1 that Parasuraman, Zeithaml and Berry (1985) elaborated as a model of service quality:

$$
\text { GAP } 5 \text { = } \mathrm{f}(\text { GAP 1, GAP 2, GAP 3, GAP 4) }
$$

Berry and Parasuraman (1992) found that the customer's perception of quality is not a one-dimensional concept. For the authors, when evaluating the quality of services, customers examine five dimensions. These dimensions are: a) Reliability; b) Responsiveness; c) Security; d) Empathy; e) Tangibility (RAZAC et al., 2013). 
The five dimensions analyzed can be defined as follows (SHAHIN; SAMEA, 2010):

1. Reliability: ability to perform the service reliably and exactly;

2. Responsiveness: ability to provide the service as promised, provide immediate care and help the client;

3. Security: ability to convey security, trust, courtesy, and knowledge to the customer;

4. Empathy: the ability of employees to provide individualized attention to clients, as well as genuine concern;

5. Tangibility: the organization's ability to provide an adequate structure of equipment, facilities, involved personnel and materials.

The final SERVQUAL model proposed by Parasuraman, Zeithaml and Berry (1988) results in 22 statements that describe the five dimensions presented, requesting respondents to classify their expectations and 22 other questions where they report their perceptions regarding the service provided (SHAHIN; JANATYAN, 2011).

Expectations and perceptions are assessed on a seven-point Likert scale, ranging from "strongly disagree" (maximum score, 7 points) to "strongly agree" (minimum score, 1 point) (MARCOVIC; RASPOR, 2010). Thus, the overall value of the quality of a service can be obtained by averaging the values of the differences between expectations and perceptions of the five large dimensions (without weighting) or by using weights derived from the importance assigned by consumers to each dimension (DOMINGUES; GOUVÊA, 2012).

The more the score shows that perceptions are below expectations, the lower the perceived quality. However, the lower the Gap between expectations and perceptions, the greater the quality of the service provided in this dimension (STATE; ISTUDOR, 2009).

SERVQUAL is a multi-item scale that shows good reliability and validity, which companies can use to understand the expectations of their customers' services (BACCARO, GALÃO, 2012). In this way, SERVQUAL is perceived as an adequate tool to measure the quality of services provided by a product development company, subsequently meeting the first specific objective established.

\section{Material and methods}

Research approaches are behaviors that seek to guide the research process. The adopted types depend on the nature of the problem, the basic theory and the proximity of the researcher to the analysis's focus object (BERTO; NAKANO, 2000). Therefore, this research is of an applied nature (PRODANOV; FREITAS, 2013, p.51) and an exploratory objective (SILVA; MENEZES, 2005). The approach to the problem is carried in a qualitative way (GERHARDT; SILVEIRA, 2009). In order to achieve the general objective proposed in this research, that is, to evaluate the quality of the services provided by a product development company, a case study was carried out following the steps proposed by Miguel (2007), presented in Table 2.

Table 2. Steps of the research.

\begin{tabular}{|l|l|l|}
\hline \multicolumn{1}{|c|}{ Step } & \multicolumn{1}{|c|}{ Goal } & \multicolumn{1}{c|}{ Realization } \\
\hline $\begin{array}{l}\text { Definition of a } \\
\text { conceptual-theoretical } \\
\text { framework }\end{array}$ & $\begin{array}{l}\text { Map literature and } \\
\text { delimit boundaries }\end{array}$ & $\begin{array}{l}\text { Data sources of the "Coordenação de Aperfeiçoamento de Pessoal de Nível Superior } \\
\text { (Capes)" was mainly used as a base. }\end{array}$ \\
\hline Case Planning & $\begin{array}{l}\text { Select analysis units } \\
\text { and means of data } \\
\text { collection. }\end{array}$ & $\begin{array}{l}\text { The selection of 37 clients for participation in the research was carried together with the } \\
\text { owner of the studied company. QuestionPro was the software defined for the distribution } \\
\text { of the paper. The Excel program was defined for data analysis. The company agreed } \\
\text { with a confidentiality agreement in order to conduct the study. }\end{array}$ \\
\hline Pilot test conduction & $\begin{array}{l}\text { Test the application } \\
\text { procedures and need of } \\
\text { adjustments }\end{array}$ & $\begin{array}{l}\text { Two of the company's clients received the questionnaire. These clients gave a } \\
\text { positive feedback on how the questionnaire was elaborated, reported that it was } \\
\text { easy to understand and there were no problems for the receipt and completion of the } \\
\text { questionnaire. There was no need for adjustments. }\end{array}$ \\
\hline Data collection & $\begin{array}{l}\text { Contact the cases and } \\
\text { record the data }\end{array}$ & $\begin{array}{l}\text { It was up to the researcher to contact the clients of the company studied (defined in the } \\
\text { case planning stage) by telephone, explaining the research and requesting the email in } \\
\text { which it could be sent. Then, each respondent received an email containing the research } \\
\text { access link. The own software used (QuestionPro) performed data recording. }\end{array}$ \\
\hline Data analysis & $\begin{array}{l}\text { Produce a narrative and } \\
\text { reduce the data }\end{array}$ & $\begin{array}{l}\text { After the data collection, the Microsoft computer program, Excel, was used for the } \\
\text { statistical analysis of the data and for the validation of the answers obtained (Cronbach's } \\
\text { alpha). }\end{array}$ \\
\hline Generate report & $\begin{array}{l}\text { Draw theoretical } \\
\text { implications }\end{array}$ & The theoretical implications were set out as this article. \\
\hline
\end{tabular}




\subsection{About the company}

The name of the organization studied will be preserved and, in this research, will be represented by Alpha Company. It is a service provider located in the city of Santa Rita do Sapucaí, Minas Gerais. This organization started its activities in 1994, that is, it has been active on the market for 20 years.

The activities carried out by Alpha Company are: i) initial contact: exchange of basic information about the client's need and the availability of the organization; ii) product requirements: definitions of aesthetics, dimensions, characteristics, materials and production process; iii) development: creation of product design according to defined requirements; iv) presentation: analysis of the developed project together with the client, aiming at the approval for the prototype production; v) prototyping: monitoring the manufacture of the prototype for analysis and visual validation, assembly and operation of the product; vi) tooling: development of the project and monitoring, together with the customer, the manufacturing of the necessary tools (injection, rotomolding, stamping, etc.); vii) manufacturing: monitoring in the manufacture and inspection of parts and tools for validation and/or eventual corrections of the project; And viii) pilot batch: follow-up in the production and assembly of the pilot batch.

It is the responsibility of the company studied: generate the $3 \mathrm{D}$ design of the product, through the software SolidWorks, within the specifications proposed by the contractor; Define the conditions and technical specifications of the materials to be used; Indicate possible suppliers of raw materials and services; Analyze the production processes that best fit and carry out all product follow-up until its validation by the contracting company.

\section{Application of the SERVQUAL scale}

In order to perform the research, it was applied the questionnaire proposed by Zeithaml, Parasuraman and Berry (1990), where the authors specify how to use the SERVQUAL tool to measure the quality of services provided.

To simplify the comprehension of the questionnaire, it had two stages. The first one aimed at measuring both the customer expectations of a product development company and what they expected from the service it offered. For this, 22 questions that addressed the five dimensions of quality were raised (tangibility, reliability, responsiveness, safety, and empathy).

The second stage of the questionnaire had as objective to measure the perceptions of the clients in relation to the services already provided by the company studied, 22 questions were developed to reach this objective.
In order to define the measurement of the 44 questions, the correspondence between sensations and numerical symbols was established in order that the variation between the symbols corresponded to the evaluation of the affirmations, for this, the Likert scale was used. Thirty-seven of the company clients received the questionnaire through a non-probabilistic sample for convenience (FREITAS et al., 2000).

Of the 37 clients evaluated, only $8.1 \%$ were female, and the majority (91.9\%) were male. Of the positions held, $69.7 \%$ of the respondents were proprietary partners and the other $30.3 \%$ had different positions.

The online software QuestionPro aided the elaboration and distribution of the questionnaire. A pilot test and Cronbach's alpha validated the questionnaire.

\subsection{Questionnaire reliability analysis}

The reliability analysis of the questionnaire (Appendix A) was performed through Cronbach's Alpha. According to Hora, Monteiro and Arica (2010) Cronbach's Alpha aims to estimate the reliability of a questionnaire applied in a survey. Cronbach's Alpha measures the correlation between the responses by analyzing the profile of the responses given by the respondents. That is, it is a mean correlation between the questions.

According to Prass, Sant'Anna and Godoy (2010), Cronbach's alpha is one of the most used psychometric indicators to determine the reliability or internal validity of an instrument. It is responsible for evaluating the internal consistency of items that aims to measure the validity of instrumental accuracy with a coefficient close to one. For the scale to be acceptable Hair et al. (2005) advise at least an alpha coefficient greater than 0.7 . Thus, the five dimensions of the expectation and perception scale of service quality can be considered adequate for the measurement that they propose, as presented in Table 3.

Thus, there was no need for rearrangements in the questionnaire, since the coefficients of Alpha for each dimension in the questionnaire were equal to or greater than 0.70 . In addition, it was not necessary to exclude any item with little correlation or join of items to form a new dimension of analysis.

\subsection{Results and discussions}

It was possible to calculate the average of the notes and, with this, the Gap of each item evaluated using the scores attributed by the clients of the company studied. Table 4 shows the average of the scores received, the standard deviation of each item analyzed and the Gaps between expectations and the perceptions of the clients studied. Measured items that have a negative sign on the front (-) mean that the expectations generated by the clients were higher than the perceptions, while those with a positive sign 
Table 3. Cronbanch's alpha.

\begin{tabular}{|c|c|c|c|c|c|c|}
\hline \multirow{2}{*}{ DIMENSIONS } & \multicolumn{3}{|c|}{ EXPECTATIONS } & \multicolumn{3}{c|}{ PERCEPTIONS } \\
\cline { 2 - 7 } & Mean & Sum of variances & Cronbach's alpha & Mean & Sum of variances & Cronbach's alpha \\
\hline Tangibility & 4.26 & 12.35 & 0.70 & 4.57 & 7.06 & 0.71 \\
\hline Reliability & 5.19 & 17.20 & 0.84 & 5.01 & 15.52 & 0.73 \\
\hline Responsiveness & 5.13 & 12.02 & 0.71 & 5.00 & 11.38 & 0.71 \\
\hline Safety & 5.16 & 15.09 & 0.73 & 5.61 & 9.77 & 0.71 \\
\hline Empathy & 5.14 & 14.20 & 0.71 & 6.19 & 3.18 & 0.73 \\
\hline
\end{tabular}

Table 4. Quality dimensions and existing Gaps.

\begin{tabular}{|c|c|c|c|c|c|}
\hline \multirow{3}{*}{ MEASURED ITENS } & \multicolumn{2}{|c|}{ PERCEPTIONS $(\mathrm{P})$} & \multicolumn{2}{|c|}{ EXPECTATIONS (E) } & GAP \\
\hline & MEAN & $\begin{array}{l}\text { STANDARD } \\
\text { DEVIATION }\end{array}$ & MEAN & $\begin{array}{l}\text { STANDARD } \\
\text { DEVIATION }\end{array}$ & \multirow[t]{2}{*}{ P-E } \\
\hline & $(\mathrm{X})$ & $(\mathrm{SD})$ & $(\mathrm{X})$ & $(\mathrm{SD})$ & \\
\hline TANGIBILITY & \multicolumn{2}{|c|}{$\alpha=0.71$} & \multicolumn{2}{|c|}{$\alpha=0.70$} & \\
\hline Modern equipment $(+)$ & 4.81 & 0.97 & 4.24 & 1.79 & 0.57 \\
\hline Good physical facilities (-) & 3.46 & 1.46 & 3.89 & 1.76 & -0.43 \\
\hline Well-dressed staff $(+)$ & 4.86 & 1.72 & 4.16 & 1.69 & 0.70 \\
\hline Attractive materials $(+)$ & 5.16 & 1.01 & 4.73 & 1.79 & 0.43 \\
\hline RELIABILITY & \multicolumn{2}{|c|}{$\alpha=0.73$} & \multicolumn{2}{|c|}{$\alpha=0.84$} & \\
\hline Punctuality of service (-) & 4.30 & 1.94 & 5.32 & 1.96 & -1.03 \\
\hline Interest in problem solving $(+)$ & 5.08 & 2.17 & 4.95 & 2.34 & 0.14 \\
\hline Perform the right first-rate service (-) & 4.84 & 1.79 & 5.16 & 1.44 & -0.32 \\
\hline Deadline accomplishments (-) & 4.59 & 1.79 & 5.49 & 1.89 & -0.89 \\
\hline Projects without errors $(+)$ & 6.22 & 0.82 & 5.03 & 1.48 & 1.19 \\
\hline RESPONSIVENESS & \multicolumn{2}{|c|}{$\alpha=0.71$} & \multicolumn{2}{|c|}{$\alpha=0.71$} & \\
\hline Establishment of deadlines (-) & 4.73 & 1.76 & 5.24 & 1.77 & -0.51 \\
\hline Ready care $(-)$ & 4.30 & 2.21 & 5.38 & 1.72 & -1.08 \\
\hline Willingness to help (+) & 6.16 & 0.90 & 5.24 & 1.75 & 0.92 \\
\hline Not busy to help $(+)$ & 4.81 & 1.61 & 4.65 & 1.69 & 0.16 \\
\hline SAFETY & \multicolumn{2}{|c|}{$\alpha=0.71$} & \multicolumn{2}{|c|}{$\alpha=0.73$} & \\
\hline Passing trust $(+)$ & 5.65 & 1.49 & 5.14 & 2.06 & 0.51 \\
\hline Transaction safety (-) & 4.86 & 2.21 & 5.51 & 1.71 & -0.65 \\
\hline Courteousness in relationships $(+)$ & 5.86 & 1.16 & 4.68 & 2.12 & 1.19 \\
\hline Knowledge $(+)$ & 6.08 & 1.14 & 5.30 & 1.85 & 0.78 \\
\hline EMPATHY & \multicolumn{2}{|c|}{$\alpha=0.73$} & \multicolumn{2}{|c|}{$\alpha=0.71$} & \\
\hline Individual attention $(+)$ & 6.46 & 0.73 & 5.03 & 1.61 & 1.43 \\
\hline Appropriate working hours $(+)$ & 6.19 & 0.78 & 5.03 & 1.71 & 1.16 \\
\hline Personalized service $(+)$ & 6.05 & 0.81 & 5.32 & 1.65 & 0.73 \\
\hline Genuine interest $(+)$ & 6.11 & 0.84 & 5.27 & 1.68 & 0.84 \\
\hline Understand specific needs $(+)$ & 6.14 & 0.82 & 5.05 & 1.78 & 1.08 \\
\hline
\end{tabular}

$(+)$ represent the items that the company studied managed to go beyond expectations customers.

According to the presented in Table 4, of the 22 items analyzed, seven items obtained a negative score, i.e. the expectations of the clients were higher than the perceptions $(\mathrm{E}>\mathrm{P})$ after the service was performed. The dimensions tangibility, reliability, responsiveness, and safety comprehend all of seven items.

The worst performing item, "ready care" (-1.08), is situated in the responsiveness dimension, which means that the organization is not available whenever a customer requires help or solving a problem. Followed by the items "punctuality of service" (-1.03) and "Deadline accomplishments" (-0.89).

The items evaluated in a satisfactory way, that is, they surpassed the expectations of the clients $(\mathrm{P}>\mathrm{E})$ in 15 items. These are distributed in the five dimensions studied. Highlighting the dimension "empathy" that obtained a positive value for all evaluated items. The item with the best performance is located in the dimension empathy and was the item "individual attention" (1.43), this means that the employees of the studied company offer a special and different service for each client of the organization, not having a standard of service or offering services. Followed by the items "projects without errors" (1.19) 
and "Courteousness in relationships" (1.19). An analysis of each dimension was also performed (Table 5).

Through the analysis of Table 3, it can be observed that the negative Gaps dimensions were reliability and responsiveness, obtaining, respectively, the scores -0.18 and -0.13 . The dimensions tangibility, safety, and empathy were positively classified by the clients of the company studied, generating positive Gaps of $0.32,0.46$ and 1.05 respectively.

In summary:

- Tangibility: it is verified that the clients had an expectation a little lower than the performance practiced by the contracted company, that is, the customer's expectations were exceeded, this is achieved by analyzing the results obtained in relation to this dimension;

- Reliability: based on the opinions of the clients interviewed, they expected the company to perform the service more reliably;

- Responsiveness: In relation to this item, customers had a higher expectation than perceived performance, that is, the ability of answers to the various questions required by customers could be improved;

- Safety: this dimension exceeded the expectation of the clients, that is, the company was beyond what customers expect;

- Empathy dimension: this dimension also exceeded in the evaluation made by the clients, presenting a lower value in the expectation compared to the performance.

Based on all the results obtained in each of the dimensions evaluated, reliability and responsiveness are the main items that require improvement by the company. That is, when the service provider promises to carry out the work in a certain time already pre-established with the client, must comply; When customers have a problem, the company should be supportive and help solve the problem; The employees of the company must convey reliability and responsibility.

Table 5. Gaps of each quality dimension.

\begin{tabular}{|c|c|c|c|}
\hline \multirow{2}{*}{ DIMENSIONS } & $\begin{array}{c}\text { PERCEPTIONS } \\
(\mathrm{P})\end{array}$ & $\begin{array}{c}\text { EXPECTATIONS } \\
(\mathrm{E})\end{array}$ & \multirow{2}{*}{$\begin{array}{c}\text { GAP } \\
(\mathrm{P}-\mathrm{E})\end{array}$} \\
\cline { 2 - 3 } & Mean & Mean & \\
\hline Tangibility & 4.57 & 4.26 & 0.32 \\
\hline Reliability & 5.01 & 5.19 & -0.18 \\
\hline Responsiveness & 5.00 & 5.13 & -0.13 \\
\hline Safety & 5.61 & 5.16 & 0.46 \\
\hline Empathy & 6.19 & 5.14 & 1.05 \\
\hline
\end{tabular}

Finally, the procedures that the company studied intends to take to improve the "reliability" dimension, considered as the weak point of the organization, are: i) to improve the specifications of the entry requirements; B) use a software to prepare a schedule that shows the correlation between the activities of all those involved in the project as well as the progress of the activities; and c) create a database for the management of knowledge about the time spent and the difficulties in performing certain types of projects.

Moreover, to value the strength of the company, it intends to focus on personalized customer service marketing, seeking loyalty to its customers and attracting new ones looking for a differential in development companies.

\section{Conclusion}

The objective of this work was to evaluate the quality of services provided by a product development organization using the SERVQUAL tool. From this general objective, the specific objectives were to analyze the use of the SERVQUAL tool for the evaluation of quality in services, evaluate the expectations and perceptions of the organization's clients from the dimensions: reliability, responsiveness, security, empathy and tangibility; and identify existing Gaps between customer expectation and perception by presenting the strengths and weaknesses of the organization. It was possible to identify that the dimension that characterizes the strong point of the organization is the empathy dimension and the weak point of the organization is in the reliability dimension.

It was verified that the SERVQUAL tool might be used to measure the quality of the services provided by a service development company, thus proving the proposition 1 made at the beginning of the research. Proposition 2 was denied, since the dimensions that presented the smallest Gap were empathy and safety, thus representing the strengths of the organization studied.

Proposition 3 also proved to be wrong with reliability and responsiveness being the weaknesses of the organization, since customer expectations were higher than their perceptions. It is thus perceived that these dimensions need to be prioritized by Alpha Company with the aim of improving, as a whole, the quality of the services offered. Finally, the company has a great opportunity for improvement, which is the reliability perceived by the customers of the service rendered, in other words Alpha Company must restructure some of its processes, as well as training its employees to transmit confidence and credibility. Therefore, all the established objectives were considered as achieved, and it is suggested as future research a detailed analysis of the impacts of these dimensions on the strategic decisions of the company. 


\section{References}

ALMEIDA, C. Concepção e desenvolvimento de um protótipo de software genérico para avaliar a qualidade em serviços utilizando o método SERVQUAL. 2013. 148 f. Dissertação (Mestrado em Engenharia)- Programa de Pós-Graduação, Universidade Federal do Paraná, Curitiba, 2013. Disponível em: <http://dspace.c3sl.ufpr.br/dspace/ handle/1884/31417? show=full $>$. Acesso em: 29 set. 2014.

AL-ROUSAN, M.; MOHAMED, B. Customer loyalty and the impacts of service quality: the case of five star hotels in Jordan. International Journal of Business and Economic Sciences, v. 2, n. 3, p. 202-208, 2010.

ARANTES, P.; NEVES, S. Avaliação da qualidade em serviços: análise da utilização da ferramenta SERVQUAL. In: ENCONTRO NACIONAL DE ENGENHARIA DE PRODUÇÃO, 34., Curitiba. Anais... Rio de Janeiro: ABEPRO, 2014.

ARMOND, P.; HORTA, P.. Qualidade no serviço de um Shopping Center por meio da aplicação da técnica SERVQUAL. Revista das Faculdades Integradas Vianna Júnior, v. 1, p. 29, 2010. Edição especial.

BACCARO, T.; GALÃO, F. O uso da escala SERVQUAL na avaliação da qualidade percebida de uma instituição bancária localizada em Londrina. Revista Cesumar Ciências Humanas e Sociais Aplicadas, v. 17, n. 1, p. 87-114, 2012.

BERRY, L.; PARASURAMAN, A. Serviços de marketing: competindo através da qualidade. São Paulo: MalteseNorma, 1992.

BERTO, R.; NAKANO, D. A produção científica nos anais do Encontro Nacional de Engenharia de Produção: um levantamento de métodos e tipos de pesquisa. Produção, v. 9 , n. 2 , p. $65-76,2000$

CHIKWENDU, D.; EJEM, E.; EZENWA, A. Evaluation of service quality of Nigerian airline using servqual model. Journal of Hospitality Management and Tourism, v. 3, n. 6, p. 117-125, 2012.

CUKIER, R.; COSTA, M. Disfunção competitiva: análise do nível de lacunas (Gaps), pelo modelo SERVQUAL, em farmácias de manipulação em municípios do estado de São Paulo. Revista Científica Hermes, v. 8, p. 70-91, 2013.

DOMINGUES, O.; GOUVÊA, M. Qualidade percebida em atividades de gerenciamento por categoria em supermercados. REGE. Revista de Gestão USP, v. 19, n. 4, p. 627-646, 2012.

FITZSIMMONS, J.; FITZSIMMONS, M. Administração de serviços: operações, estratégia e tecnologia de informação. 2. ed. Porto Alegre: Bookman, 2010.
FREITAS, H. et al. O método de pesquisa survey. Revista de Administração, v. 35, n. 3, p. 105-112, 2000.

GERHARDT, T.; SILVEIRA, D. Método de pesquisa. Porto Alegre: Editora da UFRGS, 2009.

GONÇALVES, T.; BELDERRAIN, M. Avaliação da qualidade em lan houses através da adaptação do instrumento SERVQUAL. Revista Produção Online, v. 12, n. 1, p. 248-268, 2012.

GRÖNROOS, C. Marketing: gerenciamento e serviços. 2. ed. Rio de Janeiro: Elsevier, 2003.

GRÖNROOS, C. Marketing: gerenciamento e serviços. 3. ed. Rio de Janeiro: Elsevier, 2009.

HAIR, J. et al. Fundamentos de métodos de pesquisa em administração. Porto Alegre: Bookman, 2005.

HORA, H.; MONTEIRO, G.; ARICA, J. Confiabilidade em questionários para qualidade: um estudo de caso com o coeficiente Alfa de Cronbach. Produto \& Produção, v. 11, n. 2, p. 85-103, 2010.

LARGE, O.; KONIG, T. A gap model of purchasing internal service quality: Concept, case study and internal survey. Journal Purchasing \& Supply Managt, v. 15, p. 24-32, 2009.

LAS CASAS, A. Qualidade total em serviços. 5. ed. São Paulo: Atlas, 2007.

MACÊDO, J. et al. Emprego da escala SERVQUAL na avaliação da qualidade de serviços de hospedagem durante uma romaria em Juazeiro do Norte (CE). GEPROS, v. 8, n. 2, p. 151-165, 2013.

MARCOVIC, S.; RASPOR, P.. Measuring perceived service quality using SERVQUAL: a case study of the Croatian Hotel Industry. Management, v, 5, n. 3, p. 195-209, 2010

MIGUEL, P. Estudo de caso na engenharia de produção: estruturação e recomendações para sua condução. Revista Produção, v. 17, n. 1, p. 216-229, 2007.

MINCIOTTI, S.; SANTOLIA, F.; KASPAR, C. Identificação de fatores críticos de sucesso para monitoramento do nível de satisfação de hóspedes de hotéis. Revista Turismo em Análise, v. 12, n. 1, p. 4-22, 2008.

NOGUEIRA, T.; LAS CASAS, A. Avaliação da qualidade na prestação de serviços em uma instituição e ensino superior: um estudo de caso comparativo das perspectivas dos clientes internos e externos através do uso da ferramenta SERVQUAL. Revista Perspectivas Contemporâneas, v. 4, n. 1, p. 81-100, 2009.

OLIVEIRA, R. et al. Qualidade em serviços no desenvolvimento de software: proposta de um instrumento de avaliação. Revista Gestão Organizacional, v. 5, n. 1, p. 82-92, 2012. 
PARASURAMAN, A.; ZEITHAML, V. A.; BERRY, L. L. SERVQUAL: A multiple-item scale for measuring consumer perceptions of service quality. Journal of Retailing, v. 64, n. 1, p. $12-37,1988$.

PARASURAMAN, A.; ZEITHAML, V.; BERRY, L. A conceptual model of service quality and its implications for the future research. Journal of Marketing, v. 49, n. 4, p. 41-50, 1985 .

PEREIRA, V. R.; CARVALHO, M. M.; ROTONDARO, R. G. Um estudo bibliométrico sobre a evolução da pesquisa da qualidade em serviço. Produção, v. 23, n. 2, p. 312-328, 2013. http://dx.doi.org/10.1590/S010365132012005000053 .

PRASS, R.; SANT'ANNA, L.; GODOY, L. Avaliação da qualidade de serviços prestados na área educacional através do modelo SERVQUAL. Revista Gestão Industrial, v. 6, n. 2, p. 213-231, 2010.

PRODANOV, C.; FREITAS, E. Metodologia do trabalho científico (recursos eletrônicos): métodos e técnicas da pesquisa e do trabalho acadêmico. 2. ed. Novo Hamburgo: Feevale, 2013.

RAZAC, M. et al. Adaptive of SERVQUAL model in measuring customer satisfaction towards service quality provided by Bank Islam Malaysia Berhad (BIMB) in Malaysia. International Journal of Business and Social Science, v. 4, n. 10, 2013.

SHAHIN, A.; JANATYAN, N. Estimation of custumer dissatisfation based on service quality gaps by orrelation and regression analysis in a travel agency. International Journal of Business and Management, v. 6, n. 3, 2011.
SHAHIN, A.; SAMEA, M. Developing the models of service quality gaps: a critical discussion. Business Management and Strategy Journal, v. 1, n. 1, p. 1397-1408, 2010.

SILVA, E.; MENEZES, E. Metodologia da pesquisa e elaboração de dissertação. 4. ed. Florianópolis: UFCS, 2005.

STATE, O.; ISTUDOR, N. The survey of the service quality: application to a hotel using the SERVQUAL model. Amfiteatru Economic, v. 11, n. 26, p. 419-428, 2009.

SULIEMAN, A. Basic dimensions of the (SERVQUAL model) and its impacto on the level of customer satisfaction: an empirical study of the housing bank in Karak, Joradan. European Scientific Journal, v. 9, n. 1, p. 21-34, 2013.

TEIXEIRA, C.; MEDEIROS, P.; LEE HO, L. Monitoramento on-line, através de amostras não-unitárias, do número de não conformidades por item em uma produção finita. In: ESCOLA DE MODELOS DE REGRESSÃO, 12., 2012, Fortaleza. Anais... Fortaleza: EMP, 2012.

ZANCAN, C.; SANTOS, P.; COSTA, A. Redes de meios de hospedagem no nordeste brasileiro. Caderno Virtual de Turismo, v. 13, n. 1, p. 85-104, 2013.

ZEITHAML, V.; BITNER, M. Marketing de serviços: a empresa com foco no cliente. 2. ed. Porto Alegre: Bookman, 2003.

ZEITHAML, V.; PARASURAMAN, A.; BERRY, L. Delivery quality service: balancing customer perceptions and expectation. New York: Free Press, 1990. 
Appendix A. Structure of the questionnaire applied.

\section{EXPECTATIONS}

The questions that follow must be answered considering your EXPERIENCES with companies that develop product designs. Think about what companies in this industry must possess to achieve excellence in services and ensure their satisfaction. Show how important you think the presence of these characteristics in the company that will provide such service. If you feel that this feature IS NOT essential for excellent companies, like the one you have in mind, choose the number 1. If you feel that such a feature IS essential to excellent companies, choose the number 7. If your feelings are uncertain, choose an intermediate number. There are no right or wrong answers; you just want a number that truly reflects your feelings towards companies that offer excellent quality of service.

1) Excellent project development companies possess modern-looking equipment.
( ) 7
( ) 6
( ) 5
( ) 4
( ) 3
( ) 2
( ) 1

2) The physical facilities of project development companies should be visually appealing.
( ) 7
( ) 6
( ) 5
( ) 4
( ) 3
( ) 2
( ) 1

3) Employees of project development companies should be neat and look good.
( ) 7
( ) 6
( ) 5
( ) $4 \quad$ ( ) 3
( ) 2
( ) 1

4) Materials associated with the service provided by the company (such as contracts, pamphlets and statements) must be visually appealing in excellent companies.
( ) 7
( ) 6
( ) 5
( ) 4
( ) 3
( ) 2
( ) 1

5) When excellent development companies promise to do something at a given time, they should do so.
( ) 7
( ) 6
( ) 5
( ) 4
( ) 3
( ) 2
( ) 1

6) When a customer has a problem, excellent project development companies must show sincere interest in solving it.
( ) 7
( ) 6
( ) 5
( ) 4
( ) 3
( ) $2 \quad$ ( ) 1

7) Excellent project development companies will perform the right service at the first try.
( ) 7
( ) 6
( ) 5
( ) $4 \quad$ ( ) 3
( ) $2 \quad$ ( ) 1

8) Excellent project development companies will provide their service in the period in which they have promised to do so.
( ) 7
( ) 6
( ) 5
( ) 4
( ) 3
( ) $2 \quad$ ( ) 1

9) Excellent companies will develop projects without errors.
( ) 7
( ) 6
( ) 5
( ) $4 \quad$ ( ) 3
( ) 2
( ) 1

10) Staff at great project development companies will tell you exactly when services will be provided.
( ) 7
( ) 6
( ) 5
( ) $4 \quad$ ( ) 3
( ) 2
( ) 1

11) Employees of great development companies will give prompt service to their clients.
( ) 7
( ) 6
( ) 5
( ) 4
( ) 3
( ) 2
( ) 1

12) Great company employees will always be willing to help customers.
$\begin{array}{ll}\text { ( ) } 7 & \text { ( ) } 6\end{array}$
( ) 5
( ) 4
( ) 3
( ) 2
( ) 1

13) Great development company employees will never be too busy to answer customer requests.
$\begin{array}{ll}\text { ( ) } 7 & \text { ( ) } 6\end{array}$
( ) 5
( ) 4
( ) 3
( ) 2
( ) 1

14) The behavior of employees in great companies will pass trust to their customers.
( ) $7 \quad$ ( ) 6
( ) 5
( ) 4
( ) 3
( ) 2
( ) 1 
15) Customers of excellent project development companies will feel secure in their transactions.
( ) 7
( ) 6
( ) 5
( ) 4
( ) 3
( ) 2
( ) 1

16) Great development company employees will always be courteous to customers.
( ) 7
( ) 6
( ) 5
( ) 4
( ) 3
( ) 2
( ) 1

17) Employees of excellent development companies will have the knowledge to answer customer questions.
( ) 7
( ) 6
( ) 5
( ) $4 \quad$ ( ) 3
( ) 2
( ) 1

18) Excellent development companies will give individual attention to their clients.
( ) 7
( ) 6
( ) 5
( ) 4
( ) 3
( ) 2
( ) 1

19) Great project development companies will have convenient opening hours for all their clients.
( ) 7
( ) 6
( ) 5
( ) 4
( ) 3
( ) 2
( ) 1

20) Excellent development company will have employees who will offer their clients personalized service.
( ) 7
( ) 6
( ) 5
( ) 4
( ) 3
( ) 2
( ) 1

21) Excellent development companies will demonstrate genuine interest to their customers.
( ) 7
( ) 6
( ) 5
( ) 4
( ) 3
( ) 2
( ) 1

22) Employees of great project development companies will understand the specific needs of their customers.
( ) 7
( ) 6
( ) 5
( ) $4 \quad$ ( ) 3
( ) 2
( ) 1

\section{PERCEPTIONS}

The following sets of statements pertain to your FEELINGS about the Alpha Company. For each statement, show the extent to which you believe that Alpha Company has the characteristics described. Choosing the number 1 indicates that you STRONGLY DISAGREE that the Alpha Company has this feature. Choosing the number 7 means you STRONGLY AGREE that the company has such a feature. You can mark any of the intermediate numbers that show how strong your feelings are. There are no right or wrong answers; you just want a number that truly reflects your feelings towards the Alpha Company.

1) The Alpha Company possesses visually modern equipment.
( ) 7
( ) 6
( ) 5
( ) 4
( ) 3
( ) 2
( ) 1

2) The physical facilities of Alpha Company are visually appealing.
( ) 7
( ) 6
( ) 5
( ) 4 ( ) 3
( ) 2
( ) 1

3) Alpha Company's employees are neat and look good.
( ) 7
( ) 6
( ) 5
( ) 4
( ) 3
( ) 2
( ) 1

4) The materials associated with the services provided by Alpha Company are visually appealing.
( ) 7
( ) 6
( ) 5
( ) 4
( ) 3
( ) 2
( ) 1

5) When Alpha Company promises to do something for a certain period it fulfills its promise.
( ) 7
( ) 6
( ) 5
( ) 4
( ) 3
( ) 2
( ) 1

6) When you have a problem, Alpha Company demonstrates a sincere interest in solving it.
( ) 7
( ) 6
( ) 5
( ) 4
( ) 3
( ) 2
( ) 1

7) Alpha Company performs the right service the first time it executes it.
( ) 7
( ) 6
( ) 5
( ) 4
( ) 3
( ) 2
( ) 1 
8) The Alpha Company provides the service in the time promised to do so
( ) 7
( ) 6
( ) 5
( ) $4 \quad$ ( ) 3
( ) 2
( ) 1

9) Alpha Company seeks not to make mistakes.
( ) 7
( ) 6
( ) 5
( ) 4
( ) 3
( ) 2
( ) 1

10) Alpha Company's employees speaks to you exactly when the service will be performed.
$\begin{array}{ll}\text { ( ) } 7 & \text { ( ) } 6\end{array}$
( ) 5
( ) 4
( ) 3
( ) 2 ( ) 1

11) Alpha Company's employees offers you ready service.
( ) $7 \quad$ ( ) 6
( ) 5
( ) 4
( ) 3
( ) 2 ( ) 1

12) The employees of Alpha Company are always willing to help you.
( ) 7
( ) 6
( ) 5
( ) 4
( ) 3
( ) 2
( ) 1

13) The Alpha Company employees are never too busy to answer your questions
( ) 7
( ) 6
( ) 5
( ) 4 ( ) 3
( ) 2
( ) 1

14) The behavior of the Alpha Company employees passes trust to you.
( ) 7
( ) 6
( ) 5
( ) 4 ( ) 3
( ) $2 \quad$ ( ) 1

15) You feel secure in your dealings with Alpha Company.
( )
( ) 6
( ) 5
( ) 4
( ) 3
( ) $2 \quad$ ( ) 1

16) Alpha Company's employees are consistently courteous to you.
( ) $7 \quad$ ( ) 6
( ) 5
( ) 4 ( ) 3
( ) 2 ( ) 1

17) The employees of Alpha Company have the knowledge to answer your questions.
( ) 7
( ) 6
( ) 5
( ) 4
( ) 3
( ) 2 ( ) 1

18) Alpha Company offers you individual attention.
( ) 7
( ) 6
( ) 5
( ) 4
( ) 3
( ) 2
( ) 1

19) The Alpha Company has convenient operating hours for your company.
( ) 7
( ) 6
( ) 5
( ) 4
( ) 3
( ) 2 ( ) 1

20) Alpha Company has employees who offer you personalized service.
( ) $7 \quad$ ( ) 6
( ) 5
( ) 4
( ) 3
( ) 2
( ) 1

21) Alpha Company demonstrates genuine interest in you.
( ) $7 \quad$ ( ) 6
( ) 5
( ) 4
( ) 3
( ) 2
( ) 1

22) The collaborator (s) of Alpha Company understands your specific needs.
( ) $7 \quad$ ( ) 6
( ) 5
( ) 4
( ) 3
( ) 2 ( ) 1 